Historic, Archive Document

Do not assume content reflects current scientific knowledge, policies, or practices. 



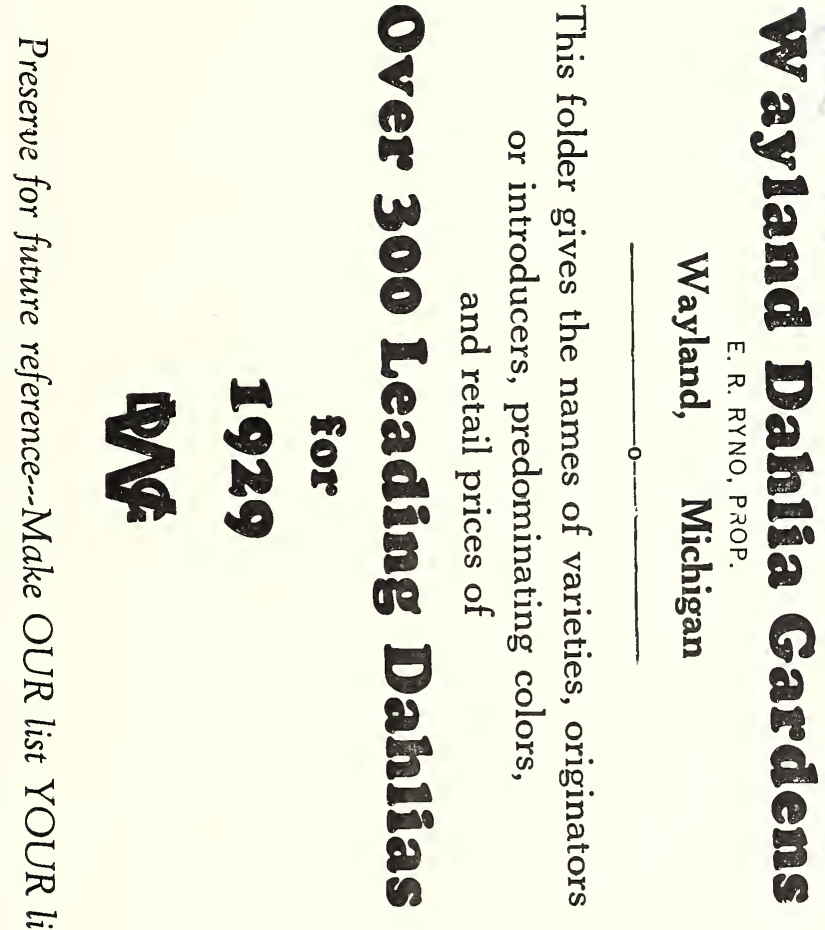

กับ

స్

$\stackrel{\varrho}{=}$

₹

छ

ह

o

\%

ई

$\stackrel{\xi}{~}$

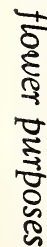

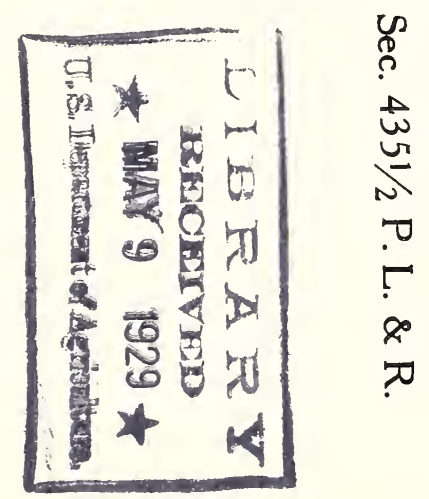





\section{Blue Label Dahlias for 1929}

\section{CACTUS AND HYBRID CACTUS}

1 Advance (Keynez) 5 carlet, base tinged yellow \$

3 Alight (burrell) Orange-scarlet -

4 Amber Glow (Boston) Amber yellow -..-

8 Ballet Girl (Boston) Orange and whit

9 Belty Austin (Peacock) Pink rose, yellow base

10
11 Bianca (Hornsveld) Roso lilac - Burke (Alexander) Yellow edged

12 Break o. Day (Maytrott) Cireanyy yellow
13
Bride's Bouguet (Wilmore) White

14 Brunhildo (Goos \& Koonemann) Plum

15 California Beauty (Booomall) Copper tints
16 California Enchantross (Bosion) Kosy pink

16 Canifornia (Nonin) White --..-
18 Celin (Broomali) Lavender pink

18 Celin (Broomail) Lavender pink -

20 Cigaretto (Boston) White edged orange

22 Clairo Kulp (Peacock) Red to orange but

23 Cockatoo (Lobbic) Yellow tipped white -..-

25 Crepusclo (Rivoire) Amber buff

27 Crystal (5tredwick). Light pink

29 Dorothy Durnbaugh (Broomall) Salmon pink

30 Earl of Pembroke (Keynes) Dark purplo
31 Edith Carier (Shoesmitt) Yellow and red

(E) Eilegant (Gill) Salmon and orange -..--

622 Emily Russel (Wilmore) Am. Beauty red

33 Esther Hunt (Boston) Urange
34 Esther R. Holmes (Lireinber B) Lavender pirk

35 Etenard de Lyon (Rivire) Purple lavender
36 Fleuriste Bizet (Stullman) Crrmmon tipped

37 white
38 Fradoran (Humphries Lobdell (Waite) Maroon
3 Fran pink

39 Francis White (Stredwick) Wbito

$40 \mathrm{French}$ Marathon (Vilmorin) Purple
$41 \mathrm{~F}$. W. Fellowes (5tredwick) Drange

42 Gay Paree, or Jean Chazot (Cayoux) Golden

57 Geo Whiz (Broomall) Buff and salmon

444 Genista (Keynes) Drange bronze -
45 George Walters (Carter) 5almon pink and

46 Cellowy Bates (Boston) Tan, reverac rose

47 Gladys 5 herwood

48 Golden Engle (Stredwick) Buff -..--
49 Golden Gate (Burbank) Ycllow amber

102 Goldten Prince (West) Golden yellow
50 Golden Wave (5tredwick) Yellow

50 Golden Wave (5tredwick) Yellow
51 Golden Weat (Broomall) Rich yellow

52 harlequin (Peacock) Red tipped whit

$53 \mathrm{H}$. H. Thomas (5tredwick) Crimson

54
55 lglam Patroa (Davies) Scarlet tipped gold

366 Jersey's Radiant (Waite) Bitterswoet orango

57 Kalif (Englehardt) 5carlet -...-.-.
58 Kreimhilde (G. \& K.) Cream and pink

60 Lady Helen (Warren) Carmine rose and

326 Lavender Beauty (Wilmore) Lavender

62 Lawine (G. \& K.) White
63 Libelle (Deegan) Dark lavender
64 Mariposa (Boston) Violet pink

29 Marjorie (astleton (Stillman) Pink and whito

65 Mary Dorr (Peacock) Pink and white ---
66 Mme. Henri (Eycux (Cayeux) Pink and white

67 Minamoto (Minamoto-Boston) Dazzling scarlet
68 Mrs. Edna Spencer (5pencer) Lavenaer pink

$68 \mathrm{Mrs}$. Edna Spencer (Spencer) Lavenaer pink
69 Mrs. Ethel F. T. 5 mith (Broomall) White --.-
71

72 Mrs. Leo Niessen (Peacock) Yellow and red

73 Mrs Warnaar (Hornsveld) White fushed pink

75 Motler (Peacock) White.
76 M. 5 hasta (5tiltman) Pin

76 Mt. Shasta (5tillman) Pink -

344 Nichu (Boston) Yellow
78 Dsprey (Alecander) Yellow

79 Pegasus (Stredwick) Cream sting
80 Perle de Lyon (Rivoire) Whit

81 Pierrot (5ircuwicls) Amber tipped wh

348 Prince of Yellows (Mortimer) Yellow -
347 Queen of Hearts (Bolgiano) Whito with yellow

82 Red Cross (Anderson) 5 carlet and gold

83 Rene Caycux (Cayeux) Red
84 Rev. T. W. Jamieson (Stredwick) Mauve pink

5 Rbeinkonig (G. \& K.) White

6 Rube Girl (Peacokc) Yellow and red

885 caramouche (Darnell) Indian red

89 Southward Ho (Bab. D. Gards.) Scarlet tipped

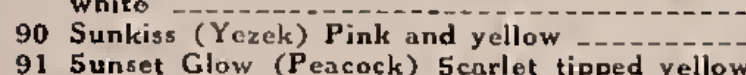

91 5unset Glow (Peacock) 5carlet

93 Thomas Dberlin (Dreer) Red

96 Walkeure (G. \& K.) Yellow and buff

979 Washington City (Broomall) White

99 Wodan (G. \& K.) Light salmon

101 Zephyr (Hobbics) Rose pink

\section{COLLARETTE}

DECORATIVE

104 A gnes Havilond (Morean) Rose pink and

370 Aellow (Lohrmann) Deep maroon - Aida (Lorlaid pink

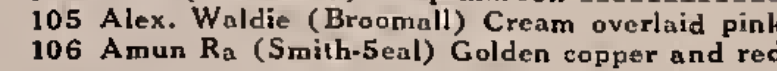

107 Augusta Nonin (Bruant) Red

109 Azalen (Boston) Creamy yellow and pink

110 Bashful Giant (Marean) Apricot and amber

11 Bon Wilson (Murphy) Red tipped yellow

112 Bessie Boston (Leedham) Deep scarlot

114 Blue Porthos (Wouters) Light purple
115 Bonnic Brne (Broomall) Cream suffused pink 117 Cardinal (Pape \& Bergmann) Dink .

118 Carmencita (Boston) Yellow striped red Filac

120 Caruso (Stillman) Yellow and roso

122 Challenge (Gill) Red and yellow

124 Champagae (Boiton) Clear chamois - 330 Charles Stratton (5tratton) Pale gold and old

125 Charm (Marean) Burnt orango

125 Claudia Tice (Finger) 5almon rose and

$\begin{array}{lr}127 \text { Clementina Wing ( } & \\ 128 \text { Clifford W. Bruton (Peacock) Yright red } & \\ 129 & \text { Collow }\end{array}$

128 Clifford W. Bruton (Pencock) Yellow

130 pink comstock (Boston) Yellow

131 Copper (Peacock) Copper tinted apricot

132 Dakota (Marean) Flame red

134 Delice (Charmot) Pink - Doazon, Souv. de Gustave (Bruant) Drange

135 Dr. Tevis (Pelicano) 5 almon rose 137 Don Wiltiams (Doolittle) 5 oft lilac tipped

138 whito Dorothy Robbins (Finger) Rich autumn shado

139 Dream (Hornsveld) Apricot and a mber

371 Dusky Princess (Boston) Dark velvety red
334 Engle Rock Beauty (Broomall) Pink and

140 Earle Williams (Doolittle) Red striped wbite

141 El Dorado (Bosxon) Yellow -..

335 Ellinor Vanderveer (5eal) Glowing rose pink

142 Elizabeth Slocombe (5locombe) Red purplo

144 Emiliana (Bohrer) Variegated red and whit

145 E. T. Bedford (Marean) Purple - Exinouth Glory (Clark) Red and orange

147 Flamingo (Ansorge) Pink

149 Florence Finger (Finger) Dark rose

150 Frank A. Walker (Alexander) Lavender pink

360 Fraternity (Gill) Delicato buff

153 Gloriana (Hodgons) Dld gold

155 Gink Golden West, or Golden Bedder (Burbank)

156 Goldmine (Pencock) Yellow 1 Whito edged

159 Halvella (McWhirter) Rose pink

328 Henry Patrick (Ware) Whit.

161 Hochsai (Doolittle) Crimson and yollow

163 yellow

363 Isabe! 5 treet (Burpee) Rose red and yellow

165 Jack Rose (Peacock) Red - pink
1655 Jane 5 elby (Boston) Mauve pink

157 J. D. Long (Wilmore) Salmon pink, amber

68 Jeanne Charmet (Charmet) Lilac pink with

59 Jerscy's Beauty (Waite) Clear pi

367 Jersey's Mammoth (Waite) Burnt orange
71 Jersey's Pride (Waite) Yellow and red -

73 Judge Alton B. Parker (Marean) Yellow buff

175 Judge Marean (Marean) Drange and red

176 Kalamazoo (

$178 \mathrm{King}$ of the Autumn (Hornsveld) Autumn
179 Kittic Dunlap (Boston) Am. Beauty shade

180 Lady Betty (Marean) Pink and white $-1 .-1$

derful Dallia was submitted to us for trial by

cause of its genuine merit we have agreed to

undertake its introduction to our thoufands of

plant is a rank grower, not affected by thri

trong stems, and a remarkably good roo

9 to 10 inches across, always full centers, under

ordinary field culture,- without disbudding.

petals of amber yellow. The largeot and hy

ever seen. Sure to be a winner for both ex

byder our own guarat

Ill our patrons to try this

of its offering-each, $\$ 10.00$; three tubers, net 15.00

purple -

182 Le Mandarin (Kunzman) Cream striped rod -

184 L. Kramer Peacock (Peacock) White

185 Lyndhurst (Dreer) Red - Creamy yellow

87 Madonna (Ware) White faintly ouffuge

188 Manzanola (Wilmore) Brilliant velvety scarlet

90 Mary C. Burno (Boston) Dld gold nnd red -

191 Mephistopheles (Marean) Red and yellow

192 Mina Burglo (Burgle) Red 193 Minnio McCullogh (Bassett) Yellow overbai

194 Mr. Crowley (Broomall) Salmon pink
195 Mr. C. H. Dresselhuys (5luis \& Groot) Pink

$196 \mathrm{Mr}$. Carl 5albach (Salbach) Lavender pink -

197 Mrs. 1. de Ver Warner (Marean) Drchid

198 Mrs. J. G. Cassatt (Vincent) Dark pink - . -

372 Mrs. John T. 5cheepers (Marean) Chamoi

200 Mrs. William Wincott (-- Wich velvety red
201 Mrs. Hug Kind (Kind) Rich

.75
.75
202 Mrs. Winters (Wihnore) White

204 Mother (Childs) Mauve pink

(Milio \& Co.) Goldea bronze

206 N. C. 4 (5tillman) Yellow and purplo

208 Dra Dow (Howell) Maroon tipped wh

209 Drnnge King (Vincent) Red orange

(Vincont) Apricot yellow and

212 Paul Michael (Michael) Did gold

215 Pride of California (Lobrmann) Red

ing salmon pink

217 Princess Juliana (Hornaveld) Waxy whi

336 Princess Pat (McWhirter) Dld rose

221 Purple Manitou (Rivoire) Purple

226 Rookwood (Boston) Pink -
337 Rosa (Broomall) Ros

337 Rose Fallon (Harding) Dld gold

331 Sagamore (Badotty) Apricot buff

352 5ebastipol (Burbank) Deep orang
229 Sequoia Gigantoa (Burns) Yellow

231 Shudow's Lavender (Boston) Lavend

233 Sulphurea (West) Yellow

235 Sylvia Dickey (Finger) Phlox pite

354 Swift (Dove) Yellow 373 The Emperor (Marean) Deep maroo

236 The Grizzly (Burns) Maroon --..-.-

239 Tommy Atkins (Boston) Yellow scarle

241 Venus (Marcan) Whito suffused lavonder
242 White Dove (5tillman) Whito

242 White Dove (5tillman) White - 243 William Slocombe (5locombe) Yellow

245 Wizard of Dz (Doolittle) Amber pink

246 World's Wonder (5tillman) Yellow salmon
247 Yellow Chrysanthemum (Broomall) Yellow

247 Yellow Chrysanthemum (Broomall) Yellow

$\begin{array}{r}.35 \\ .25 \\ .50 \\ .35 \\ 1.50 \\ 1.00 \\ .75 \\ .35 \\ .25 \\ .35 \\ .35 \\ .50 \\ 1.00 \\ .25 \\ .50 \\ .35 \\ 1.00 \\ .25 \\ .35 \\ 1.00 \\ 1.00 \\ .50 \\ .25 \\ .25 \\ 1.00 \\ 1.00 \\ .75 \\ 3.00 \\ .50 \\ 1.50 \\ 1.00 \\ .35 \\ .50 \\ .75 \\ .75 \\ 1.50 \\ .75 \\ .50 \\ .25 \\ .50 \\ .50 \\ .50 \\ .75 \\ .50 \\ .50 \\ 1.00 \\ 1.00 \\ .50 \\ .35 \\ 1.00 \\ 1.00 \\ 1.00 \\ 1.50 \\ .75 \\ 1.00 \\ .35 \\ .25 \\ \\ \hline\end{array}$

PEONY-FLOWERED OR ART DAHLIAS

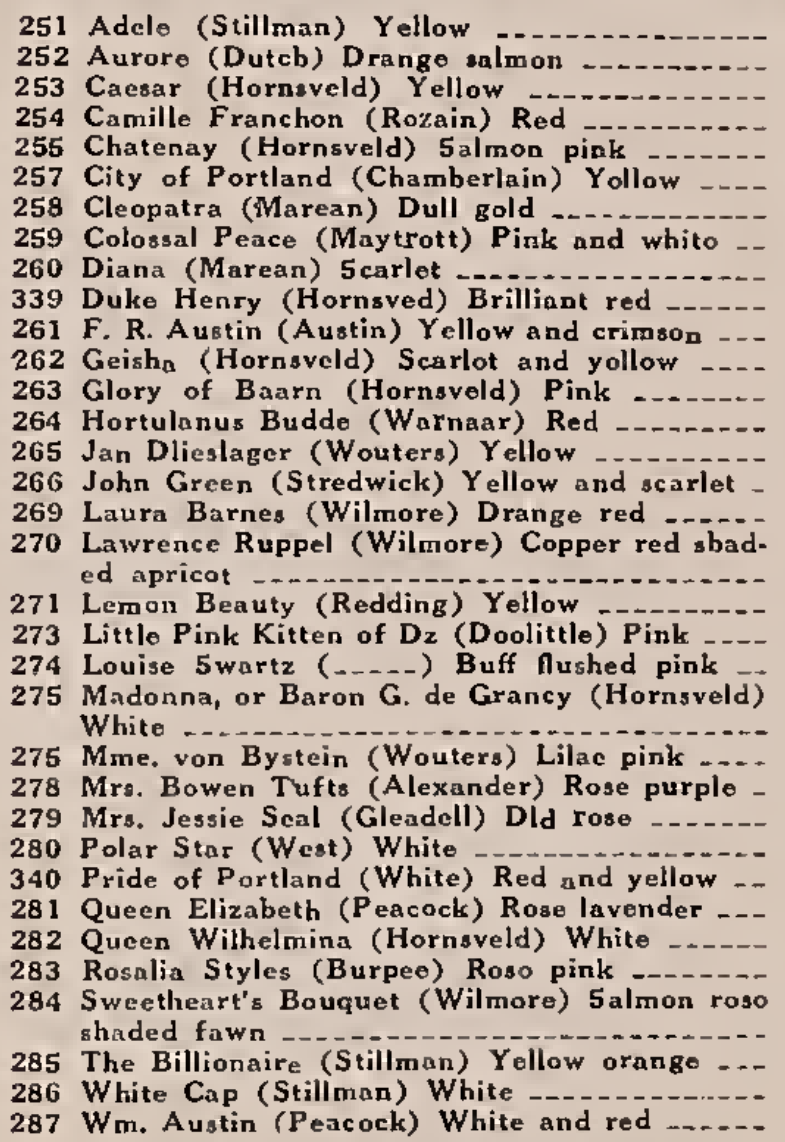

\section{.25
.35
.25
1.00}

.00

\section{.50
.50
.35}

SHOW AND FANCY SHOW

288 A. D. Livoni (5torrs \& Harrison) Rose pink

291 Bertho Bernstein (Gero) Derk

292 Black Hussar (Ind. Dahlia Farms) Maroo

293 Bonnic Blue (Archer) Bluisb - Clara 5eaton (Reidy-Doolittlo) Yellow brown

296 David Warfield (Humphries) Red -

298 Dorothy De La Mare (Peacock) Pin

300 D. M. Moore (Wilmore) Maroo

01 Dreer's White (Dreer) White

303 Elsie Burgess (Childs) White

305 Gorld Me Lyon (_----) White - -

327 Grand Duchess Mario (Gill) Brown orang

307 Mean Kerr (Burpee) White - Augusta Le Maire (Alexander) Yellow

308 Manzanita (Wilmore) Lavender 309 Mile. Lily Large (Alexander) Yellowish red

311 Maude Adams (Alexander) White and pink

312 Miss Helen Hollis (Alexander) Scarlet ....

313 Drator (Kunzman) Buff and white

315 Queen Victoria (Vick) Yellow -.

316 Red Hussar (Dreer) Red Whito

319 Tillamook (Gill) Blush
320 Vivian (Alexander) Whito tipped purplo
321 Warrior (Keynes) Red

322 White Swan (Stillman) Wbito
324 Yellow Duke (Bassett) Yellow 



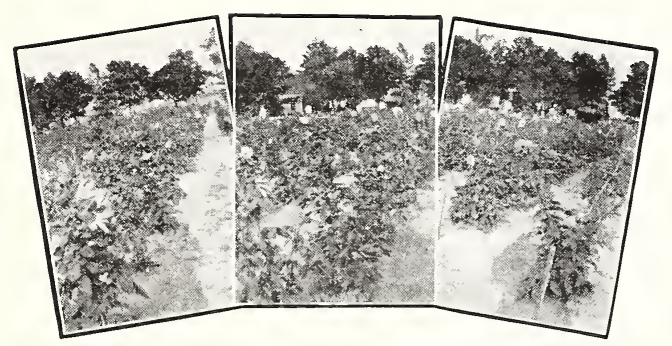

Views of our trial grounds

We test hundreds of varieties here before offering to our patrons

\section{Special Offer to Early Buyers}

So many customers hold their orders until April or May when we are right in the midst of our shipping season that it makes it necessary for us to add extra help and work overtime to handle these late orders. That we may be able to give the best service, we therefore urge our patrons to order early; and as a special inducement to this end we will include with every order received during January and February, one tuber of some good named variety of Dahlia from our trial grounds of the past year. This means some variety that we have found satisfactory and will list for the first time next year, so you can count on getting something really good and as yet new to our customers. Don't delay. Send your order promptly while our stock is complete.

Professor W. D. Cramer, of the nationally known Ferris Institute, of Big Rapids, Mich., writes us as follows:"My stock from you has done very well indeed. Some blossoms, such as The Billionaire, and Bashful Giant, have run from six to nine inches. One of the latter now is 9 inches across. I am telling many people where I got my roots, and you will no doub't get lots of orders from here next year."

A customer in North Carolina writes that she "never had as good tubers as those you sent me last year. Every one came up and all are in full bloom now. Am more than pleased and you will surely get orders from myself and friends next spring."

\section{BANK BY MAIL}

If you do not have a savings account, or if you now have one but do not wish to "put all your eggs in one basket," or are getting a lower rate of interest, write for our plan of Banking by Mail.

\section{WE PAY 4\% ON SAVINGS DEPOSITS}

We have been established right here in the heart of one of the richest farming and dairying sections in Michigan for more than twenty-five years, and have over three-quarters of a million dollars resources.

We are under State Supervision, and can assure you absolute safety with the most courteous treatment.

Write us today.

Wayland State Bank Wayland, 


\section{Special Dahlia Collections}

\section{for 1929}

Some of the greatest bargains that have ever been offered. All first class tubers, and of the best varieties, priced low so you can enjoy the pleasure of having the finest dahlias in your neighborhood.

DAHLIA COLLECTION No. 1. Six Fine Dahlias for the Home Garden. $\$ 1.00$ postpaid.

For the past two years this has been one of our most popular collections, comprising as it does, six of the very best dahlias for the amateur grower.

1 Kreimhilde, Cactus, Cream and pink.

1 Rene Caveux, Cactus. Rich cardinal red.

1 Doazon, Decorative, Orange-scarlet. Very large.

1 Jeanne Charmet, Decorative, Lilac-pink.

1 Arabella. Show, Yellow and rose.

1_Storm King, Show, White.

We quote from a letter received from a lady in Gordon, Ohio, who included this collection in her order, together with several other varieties:-

"The past two weeks I have had such gorgeous blossoms that I run out to my flower garden several times a day; and with so many of the neighbors coming and going to the row of Dahlias the soil has become a verv haro path near Bride's Bouquet-(I frequently hoe the beaten soil) - the second in the row is Rene Cayeux, which has tried to excel the Bride's Bouquet: then next to bloom, fifth in row, is Souv. de Gustave Doaron. which has been a marvel, $6 \frac{1}{2}$ inches in diameter. Ladies from a town five miles away came to see it Sunday P. M. Then sixth in row is Kreimhilde, which is a beauty. Storm King will be the next to show off. After the gorgeous blossoms came and I found they were far superior to those of all old dahlia growers in our hamlet. I was so delighted that if I am able nhysically I shall nurchase more another year. Mariorie Castleton (that is the gratic dahlia you sent) is looking fine, has several buds. Everybody is asking where I got such wonderful dahlias."

DAHLIA COLLECTION No. 2. Four World's Best Dahlias for Garden and Exhibition Purposes, $\$ 1.00$ postpaid.

We sold this collection for $\$ 200$ last vear, and have cut the nrice in two this year iust to enable nur patrons to see what these truly wonderful dahlias will do for them. All are giant flowering varieties that will surely please you.

1 Bonnie Brae, Decorative, Cream suffused pink.

1 Mrs. T. de Ver Warner, Decorative, Orchid lavender.

1 Patrick O'Mara, Decorative, Apricot. yellow, orange.

1 Pride of California, Decorative, Red.

The two collections above should be included in every order-iust think of it-ten really high class dahlias for $\$ 2.00$. Can you beat it?

DAHLIA COLLECTION No. 3. Six Wonderful Dahlias for the Show Garden and Cut Flowers. $\$ 1.00$ postpaid.

This collection was our leader last year, and from the mary orders received from all narts of the United States. we hat nothing but the highest praise. Here is a sample letter received from a lady in Joplin, Mo. 


\section{How to Pack Dahlia Blooms}

In response to the many inquiries from our customers regarding the proper method of packing cut dahlia blooms for the large city markets, we are reprinting the following article from The FLORISTS' REVIEW, through the ccurtesy of the Florists' Publishing Co., Publishers, 508 South Dearborn St., Chicago.

\section{PACKING DAHLIAS}

Dahlias have become a staple fall flower in the Philadelphia market. The key to their popularity lies in the eliminating of handling. Improved varieties in rich or autumnal shade, better culture and quick transportation all play their part in the wonderful progress that has been made with the dahlia, but no one of these things nor all of them combined could have made the dahlia popular under the old system of handling.

Dahlias are too brittle to stand packing as cther flowers are packed, unpacking, repacking and subjecting to the ordinary wear and tear to which cut flowers are subjected.

Practically all the dahlias that come into the Philadelphia cut flower market are packed at the farm on orders, as it is termed; that is, the wholesaler orders the number of boxes of each variety that he thinks his business will require and delivers these boxes exactly as he receives them, merely lifting a lid now and then to see that they are all right and true to name. The packing is usually done in corrugated boxes, $5 \times 15 \times 42$. The flowers, all disbudded stock, borne on long stems from twelve to eighteen inches long, are cut when fully developed, excepting on special and long distance orders. They are packed fifty to sixty or seventy-five, according to size of flower, in a box lined with brown tissue paper. The packing is done singly from both ends, so that the stems overlap in the middle. A single lath cleat is then tacked midway across the box, with a nail piercing a tin cap at each side. At the most progressive dahlia farm, the flowers are cut during the day and immediately plunged into water. There they remain until a little after midnight. when the packing begins. When three or four boxes are packed, they are placed in a lath crate re-enforced at the ends. When all the crates are packed, they are loaded on trucks and sent to Philadelphia in time to arrive at the opening of the market, $7: 30$ a. $m$.

An important aid to keeping qualities of the dahlias is to plunge the stems in hot, not boiling, water: When properly done, this will double the life of the flower after cutting. -Phil.

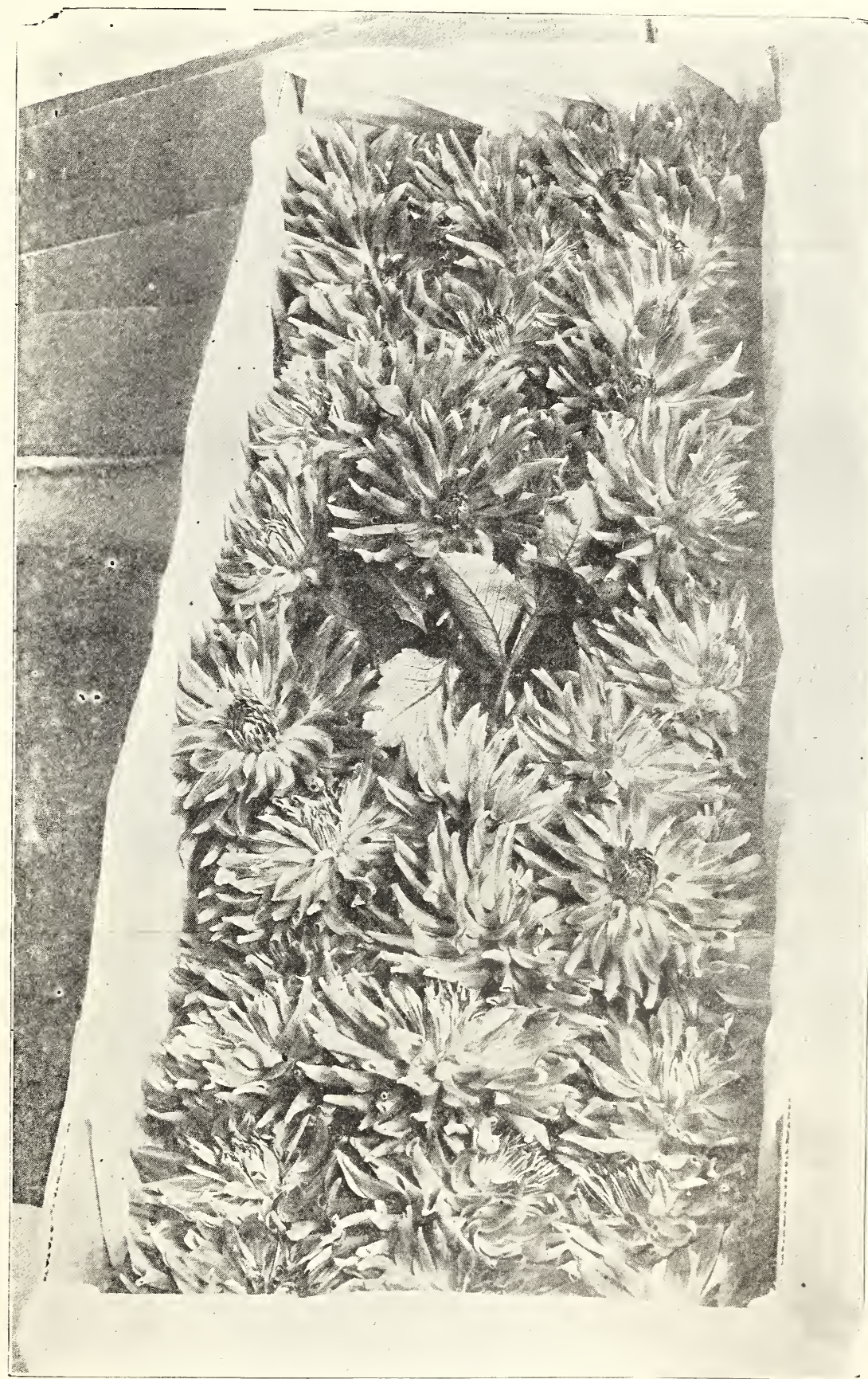

Box of Mah Jong Dahlias Packed for the Philadelphia Market

\section{Wayland Dahlia Gardens, Wayland, Michigan}




\section{How To Grow Dahlias}

\section{Brief Cultural Directions}

Dahlias do well in any well drained fertile garden soil in an open sunny location, and are as easy to grow as potatoes.

Before planting spade the ground well to loosen the soil thoroughly to a depth of six to eight inches.

When soil is warm and danger of frost is past, dig holes five or six inches deep, two to three feet apart, in rows three to four feet apart.

Lay tuber on its side-never on end-with eye upward, and cover with good dirt in which is mixed a little wood ashes if possible. Mark place of hill with a small stick. Sprout should show within three weeks. If at the end of that time, no sprout is visible, return to us and we will replace the tuber. We are very careful in dividing: clumps and seldom have tubers returned, but we want you to feel that we are interested in your success, and are always willing to make grood any of our stock that may prove to be unsatisfactory.

After plant is up, remove all but one sprout. When this has grown to be twelve to fifteen inches high, pinch out the top to encourage lower branching and make it unnecessary to stake plant to keep from breaking over by wind.

When buds show, remove all but one bud on a stem, removing shoots and leaves at base of bud to give a better sțem. Allow five or six blooming stems to a plant, and keep all dead flowers trimmed off.

During blooming season give plenty of fertilizer to the plant, placing around the hill, a few inches from the plant, work well into the soil and be sure to see that plant does not have growth checked for want of water.

Quite an interesting little work on "Dahlias for the Home"-Farmer's Bulletin No. 1370-may be obtained from the Supt. of Documents, Gov't. Printing Office, Washington, D. C. for 5c. We advise our friends to send for it. Also "Dahlias in the Garden," Circular No. 154, New Jersey Experiment Station, New Brunswick, N. J. We suggest that you send a dime or more for this last work if you are not a resident of New Jersey, because it is probably intended only for distribution among residents of that state.

A Few Ion'ts:-

Don't condemn a small tuber. Many of the largest and best varieties make ver'y small tubers.

Don't plant too early. The dahlia is a fall flower, and if planted too early will commence to bloom in the hottest weather, and either blast in the bud or produce one-sided flowers.

Don't unwrap tubers until ready to plant.

Don't store in light, hot or dry room. We send out only nice, clean, plump, well-matured tubers, and if properly handled they will remain in this condition for weeks; but if exposed to light and warm, dry air, they must be expected to dry out and shrivel.

Don't stand tuber on end. Plant flat in the bottom of the hill, with eye upward.

Don't plant too shallow. Usually five to six inches deep is best in the averag'e garden soil.

Don't neglect aphis and thrips. If leaves begin to turn brown and die at tips, spray well with Black Leaf 40 , one or two teaspoonfuls to a galion of water, with a handful of Lux or other soap flakes, to make solution spread well. Be sure to wet uncler side of leaves, and if one application does not stop the trouble, repeat with another.

\section{Wayland Dahila Gardens}




\section{saInd

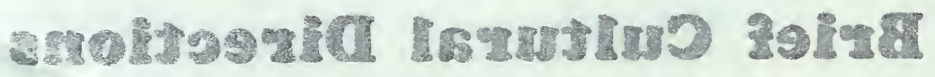

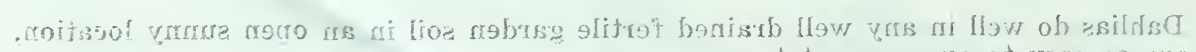

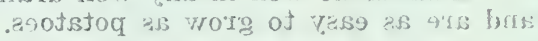

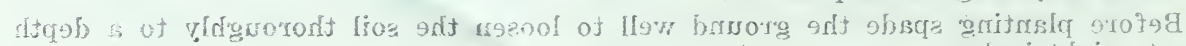
zindori trigis of xiz in

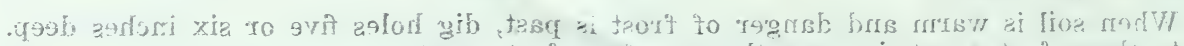

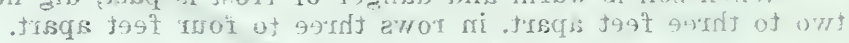

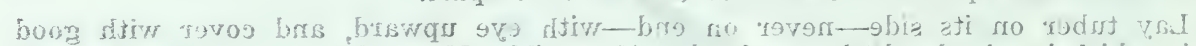

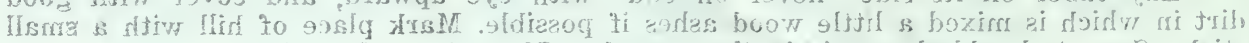

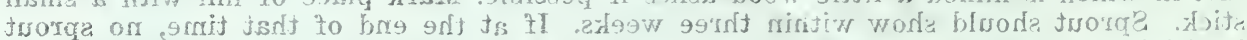

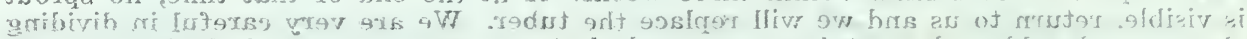

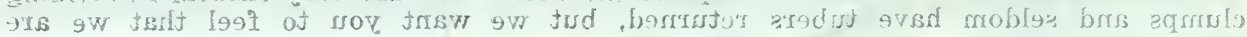

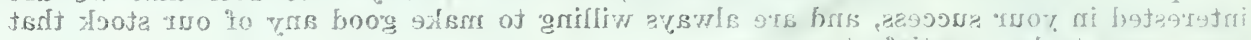
. Virotosteifsanus ad of grome vism

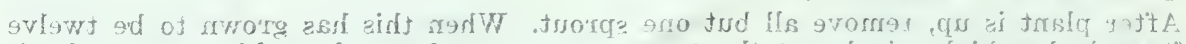

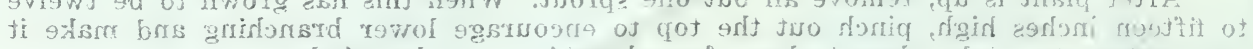

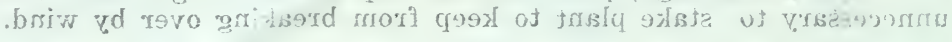

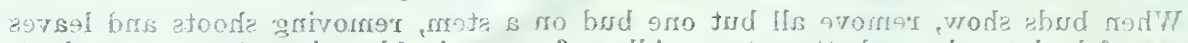

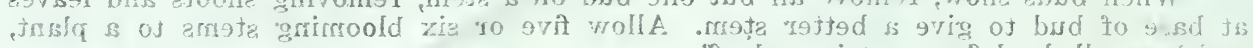

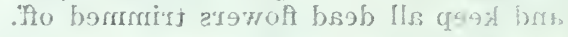

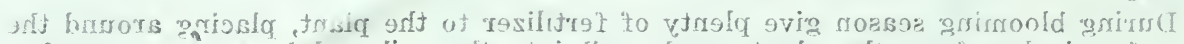

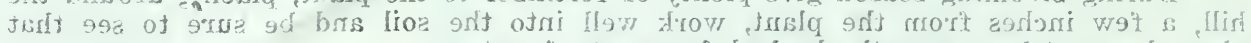

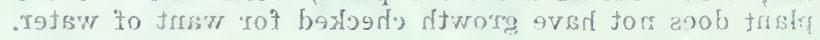

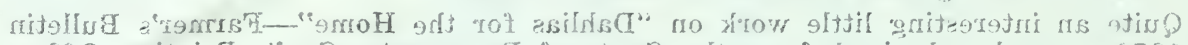

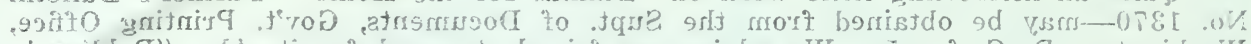

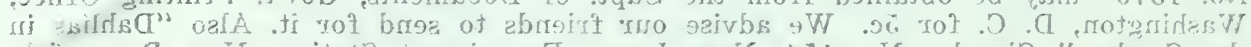

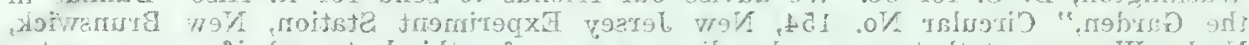

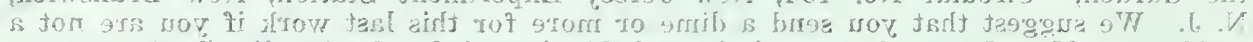

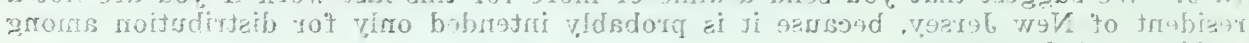
ofsta jodit to etrafizas - astrol $\mathrm{va}$ म $\mathrm{A}$.

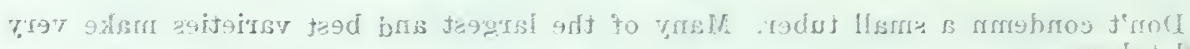
.exiendest linist:

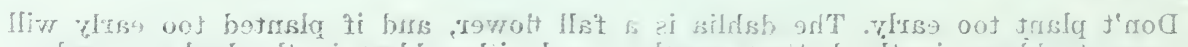

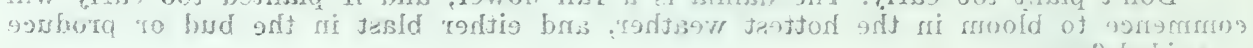
$.519 \mathrm{k}$ of bobis-3ro

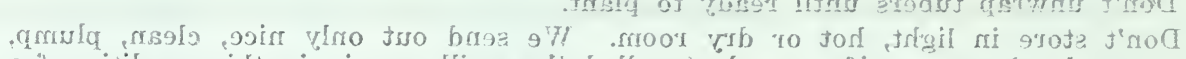

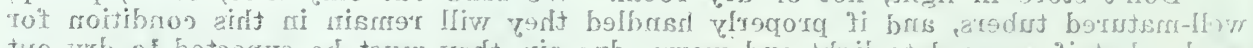

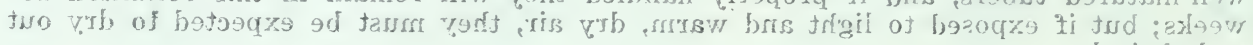
.Isvirisa borst

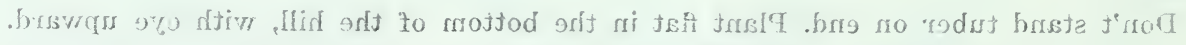

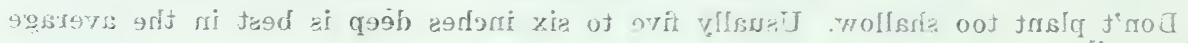

lioe nobrest

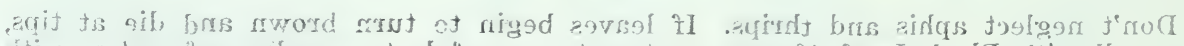

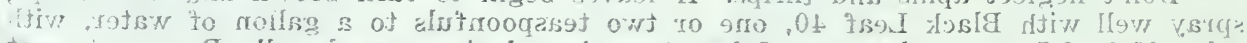

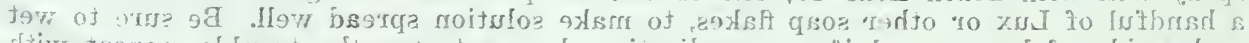

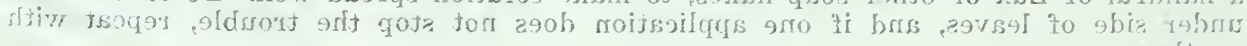

igriforis

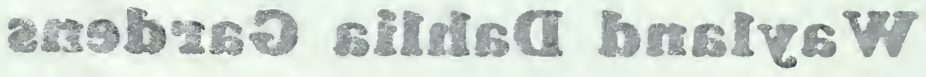




\section{Gentlemen:-}

I visited a friend yesterday in Pittsburg who was the proud owner of a beautiful collection of dahlias that he ordered from you last spring; and I am wondering if you will still have it next year, as I very much want it. The collection was No. 3, and price one dollar. Will you be so kind as to put ne on your mailing list and send me a catalog next time you have one? I can hardly wait till next year.

Thanking you, I am,

So you see, the collection is able to speak for itself. Here it is. Don't omit it from your order.

1 Bertha Horne-a bronzy yellow and apricot hybrid cactus, awarded Certificate of Merit by the American Dahlia Society.

1 Diana-an immence crimson and violet reflex cactus.

1 Darlene-an older variety, but still one of the finest shell pink decoratives.

1 Sebastipol-a wonderful deep orange decorative -one of the late Luther Burbank's best.

1 Swift-a massive sulphur yellow decorative.

1 Aurore-a rich deep bronzy apricot and orange decorative-peony-flowered dahlia that a prominent grower describes as "one of the most attractive dahlias in his collection-a close rival to Patrick O'Mara, and perhaps a little better."

\section{DAHLIA COLLECTION No. 11. Six Beautiful Dahlias for $\$ 1.00$ postpaid.}

This collection was offered only on our envelopes last year, yet we sold hundreds of them, mostly to customers who had already placed an order from our catalog. No matter how many varieties of dahlias you grow, you will want these standard sorts, and purchased singly, they would cost about double what we ask for them in this collection.

1 Lawine, Cactus, White.

1 Libelle, Cartus, Dark lavender.

1 Frank A. Walker. Decorative. Pink.

1 Oregon Beauty, Decorative. Red.

1 Maude Adams, Show, White and pink.

1 Yellow Duke, Show, Yellow.

A lady in Syracuse, N. Y., writes-"Tried out your dahlias, and have decided to plant quite a few next spring. I agree they are quite the most satisfactory bulbs, and blooming in the fall are much appreciated."

DAHLIA COLleCtion No. 6. Six Very Finest PeonyFlowered or Art Dahlias. $\$ 2.00$ postpaid.

No dahlia garden is complete without a fair representation of the beautiful Peony-flowered or Art dahlias; and we can unhesitatingly recommend these six varieties as the very best of the type:-

1 Cleonatra, beautiful dull gold shade-a Marean dahlia of the highest class.

1 Colossal Peace, a peony-cactus type dahlia of delicate pink and white color. Very large.

1 Diana. Large, brilliant scarlet. Another Marean dahlia of great merit.

1 Pride of Portland, a beautiful flower of brighter Geisha colors.

1 Rosalia Styles, Large, rose-pink. Very profuse bloomer.

1 The Billionaire, Golden orange. One of the finest dahlias grown. 
DAHLiA COLLECTION No. 7. Six Beautiful Cut Flower Dahlias, $\$ 2.00$ postpaid.

1 Geo. Walters, Hybrid cactus, Salmon pink and yellow.

1 Dr. Tevis, Decorative, Salmon rose, gold and apricot.

1 Giant Ruby, Decorative, Brilliant red.

1 Judge Alton B. Parker, Decorative, Yellow buff.

1 Mrs. Carl Salbach, Decorative, Lavender pink.

1 The Millionaire, Decorative, Lavender pink.

DAHLia Collection No. 8. Six More Cut Flower Dahlias. $\$ 2.00$ postpaid.

1 Mrs. Warnaar, Hybrid cactus, White flushed pink.

1 Red Cross, Hybrid cactus, Scarlet and gold.

1 John Lewis Childs, Decorative, Red, white and yellow.

1 Mrs. Hugo Kind, Decorative, Rich velvety red.

1 Queen Mary, Decorative, Rose pink.

1 Rosemawr. Decorative, Rose pink.

Collections No. 6, 7 and 8, make a beautiful assortment for the home garden, and the giant blooms will always kring in the neighbors.

DAHLIA COLLECTION No. 10. "FLORISTS' REVIEW"

Coll ction of 20 Cut Flower Dahlias. $\$ 6.00$ postpaid.

The FLORISTS' REVIEW, America's greatest floral trade paper, recommends the following list of Dahlias "that lead for cut-flower purposes"-

\section{Decorative Type}

Jersey's Beauty, true pink without any markings.

Jurge Marean, salmon pink, red, iridescent orange, yellow and gold, all blending.

Mrs. I. de Ver Warner, a deep mauve pink.

Rosa Nell, bright rose.

Charm, burnt orange, shading to yellow.

Delice, glowing rose-pink.

Insulinde. caffron yellow suffused russet-orange.

Patrick O'Mara. orange-buff. slightly tinged deep rose. Sylvia. white, shading to soft nink on outer petals.

The Millionaire, delicate lavender with faint pink cast.

\section{Cactus Type}

Countess of Lonsdale, delicate apricot.

Bianca, lilac-rose.

Golden West, golden bronzy yellow, with scarlet shading.

\section{Peony-Flowered Type}

Jan Olieslager, deep primrose yellow.

Queen Wilhelmina, pure white with yellow center.

\section{Show Type}

A. D. Livoni, soft pink.

Dorothy Peacock, bright seashell pink.

Jean Kerr, pure white.

Stradella. deep purple crimson.

Yellow Duke, pure canary yellow.

If you want a collection of Dahlias that will make your garden the outstanding feature in your community, or if you want to start in the "Dahlia business" for the purpose of selling either cut-flowers or tubers, we know of no assortment that will meet your requirements so perfectly as this collection. And at the low price quoted this year for the entire assortment, we are sure you could make no better investment in this line. Twenty varieties, all of them the hest in their class. one tuber of each variety, all carefully wranped and labelled, delivered to your address for only Six dollars. 


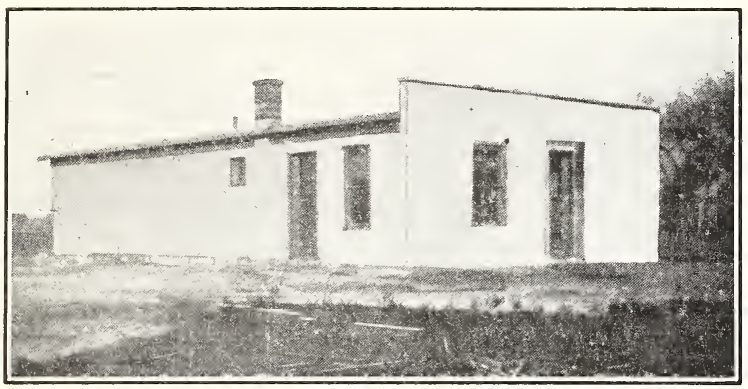

View of our new office and frost-proof Dahlia storage cellar. Here we have space for storing and handling a million dahlia tubers each season, together with all modern facilities for taking care of our customers' orders in a thoroughly satisfactory manner.

\section{GENERAL INIFORMATION}

\section{HOW TO ORDER}

Orders may be sent my mail or placed personally at our office. Cash in full should accompany all orders. Remit by any approved method-check, post-office or express money order or registered letter. Please do not send stamps if amount is over $\$ 1.00$.

\section{TIME OF SHIPMENT}

All orders will be filled in rotation after April 1st, unless otherwise specified in order, in which case customer must assume all responsibility for damage from frost. We begin dividing clumps soon after digging and can usually supply any variety in quantity by February 1st. or later if so desired.

\section{PACKING AND TRANSPORTATION}

We pack and deliver all tubers to your address without extra charge at prices quoted in this list, and guarantee safe arrival in all cases.

Cultural directions accompany all shipments.

\section{GUARANTEE}

All tubers are strong, healthy divisions of field-grown clumps which are tagged when in bloom and absolutely guaranteed to conform to description. We also guarantee every tuber to show sprout within three weeks from time of planting or same will be replaced free of charge upon return to us.

\section{REFERENCE}

We refer to the Wayland State Bank, Wayland, Mich., as to our responsibility.

\section{VISITORS WELCOME}

The varieties listed herein, and many others, both old and new, may be seen in all their glory of bloom at our gardens, located on the Mackinaw Trail (U. S. 131) in the village of Wayland, 21 miles south of Grand Rapids and 28 miles north of Kalamazoo, from August 1st until frost. Visitors are cordially invited and welcome at all times.

Order early. Always give full name and address when writing to us.

\section{Wayland Dahlia Gardens}


